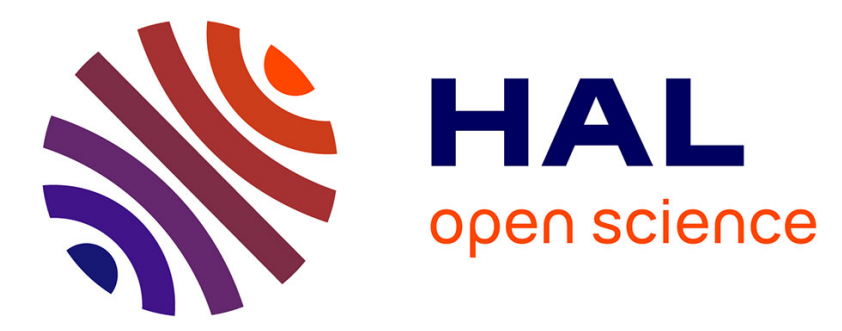

\title{
Electrochemical performances in temperature for a C-containing LiFePO4 composite synthesized at high temperature
}

Magalie Maccario, Laurence Croguennec, F. Le Cras, Claude Delmas

\section{- To cite this version:}

Magalie Maccario, Laurence Croguennec, F. Le Cras, Claude Delmas. Electrochemical performances in temperature for a C-containing $\mathrm{LiFePO} 4$ composite synthesized at high temperature. Journal of Power Sources, 2008, 183 (1), pp.411-417. 10.1016/j.jpowsour.2008.05.045 . hal-00324671

\section{HAL Id: hal-00324671 \\ https://hal.science/hal-00324671}

Submitted on 25 Sep 2008

HAL is a multi-disciplinary open access archive for the deposit and dissemination of scientific research documents, whether they are published or not. The documents may come from teaching and research institutions in France or abroad, or from public or private research centers.
L'archive ouverte pluridisciplinaire HAL, est destinée au dépôt et à la diffusion de documents scientifiques de niveau recherche, publiés ou non, émanant des établissements d'enseignement et de recherche français ou étrangers, des laboratoires publics ou privés. 


\title{
Electrochemical performances in temperature for a $\mathrm{C}$ - containing $\mathrm{LiFePO}_{4}$ composite synthesized at high temperature
}

\author{
M. Maccario ${ }^{a}$, L. Croguennec ${ }^{\mathrm{a}, *}$, F. Le Cras ${ }^{\mathrm{b}}$ and C. Delmas ${ }^{\text {a }}$ \\ ${ }^{a}$ Institut de Chimie de la Matière Condensée de Bordeaux-CNRS and ENSCPB, Université Bordeaux 1 \\ 87 Av. Schweitzer, 33608 PESSAC cedex, France \\ ${ }^{b}$ Commissariat à l'Energie Atomique, Laboratoire Composants pour l'Energie DRT/LITEN/DTNM/LCE, 17, rue des Martyrs, 38054 Grenoble cedex 9, France
}

\begin{abstract}
$\mathrm{C}-\mathrm{LiFePO}{ }_{4}$ composite was synthesized by mechanochemical activation using iron and lithium phosphates and also cellulose as carbon precursor; this mixture was heated at $800^{\circ} \mathrm{C}$ under argon during a short time. Long range cyclings at different temperatures $\left(\mathrm{RT}, 40^{\circ} \mathrm{C}\right.$ and $\left.60^{\circ} \mathrm{C}\right)$ and at $\mathrm{C} / 20$ rate between 2 and $4.5 \mathrm{~V} v$. $\mathrm{Li}^{+} / \mathrm{Li}$ were carried out with this $\mathrm{C}-\mathrm{LiFePO}_{4}$ composite as positive electrode material in lithium cells. Whatever the cycling conditions used, rather good electrochemical performances were obtained, with a capacity close to the theoretical one and a good cycle life, especially at RT - up to 100 cycles - and at $40^{\circ} \mathrm{C}$ with $\sim 80 \%$ of the initial capacity maintained after 100 cycles. The electrodes recovered after long range cycling were characterized by X-ray diffraction; whatever the cycling temperature no significant structural changes (cell parameters, bond lengths, ...) were shown to occur. Nevertheless, iron was found to be present at the negative electrode - as already observed by Amine and co-workers - after long range cycling at $60^{\circ} \mathrm{C}$ : other analyses have to be done to identify the origin of this iron (from an impurity or from $\mathrm{LiFePO}_{4}$ itself) and to quantify this amount $v s$. that of active $\mathrm{C}$ - $\mathrm{LiFePO}_{4}$ material using larger cells.
\end{abstract}

Keywords: lithium-ion batteries, $\mathrm{LiFePO}_{4}$, electrochemical properties, cycling in temperature, structural stability, $\mathrm{X}$-ray diffraction

\section{Introduction}

The increasing use of lithium-ion batteries in space, automotive and portable applications leads to numerous researches to improve the positive electrode materials already used [1] but also to develop new materials. So, since the work of Padhi et al. in 1997 [2], olivine-like $\mathrm{LiFePO}_{4}$ appears as an interesting positive electrode material for lithium-ion batteries and has thus been widely studied in the last few years [3-7]. The main issue for $\mathrm{LiFePO}_{4}$ is its low conductivity [6,8]. Optimization of $\mathrm{LiFePO}_{4}$ for good electrochemical performances in lithium-ion batteries has been mainly achieved by synthesizing small particles [9] and by forming an electronic conductive coating, that being often a carbon coating [10-12]. Note that the addition of metallic agents such as $\mathrm{Ag}$ and $\mathrm{Cu}$ has been also considered to overcome the low electronic conductivity [13]. More recently, Delacourt et al. have synthesized by direct precipitation and $\mathrm{pH}$ control a carbon-free $\mathrm{LiFePO}_{4}$ sample with very small particles $(140 \mathrm{~nm})$, that shows also optimized electrochemical performances with a good reversible capacity of $145 \mathrm{mAh} / \mathrm{g}$ at C/2 rate [14].

The main goal of our study was at first, as described in reference [15], to explore different synthesis conditions, then to characterize the $\mathrm{C}-\mathrm{LiFePO}_{4}$ composites synthesized and finally to correlate their physico-chemical and electrochemical properties. Note that whatever the synthesis parameter modified, no significant structural and physico-chemical differences are observed between the $\mathrm{C}-\mathrm{LiFePO}_{4}$ composites synthesized, except for small differences - difficult to characterize - from a microstructure point of view (particles and agglomerates size distribution, pore size distribution and nature of carbon coating). Nevertheless, all of these $\mathrm{C}-\mathrm{LiFePO}_{4}$ composites show electrochemical properties significantly different from each others, suggesting thus that the microstructure of the composites

* Corresponding author (L. Croguennec)

Tel.: +33-5-4000-2647 (or 2234) Fax: +33-5-4000-2761

E-mail address: laurence.croguennec@icmcb-bordeaux.cnrs.fr would be the major key factor to control for optimized electrochemical performances.

Optimized $\mathrm{LiFePO}_{4}$ materials deliver at room temperature reversible capacity close to the theoretical one (i.e. $170 \mathrm{mAh} / \mathrm{g}$ ) $[16,17]$. The lithium intercalation/deintercalation reaction occurs as a two-phase reaction between a lithium-rich phase $\left(\mathrm{Li}_{1-\varepsilon} \mathrm{FePO}_{4}, \varepsilon \rightarrow 0\right)$ and a lithium-deficient phase $\left(\mathrm{Li}_{\mathcal{\varepsilon}}, \mathrm{FePO}\right.$, $\varepsilon \rightarrow 0)$ at a $\sim 3.45 \mathrm{~V}$ voltage $v s . \mathrm{Li}^{+} / \mathrm{Li}[2,18]$, two narrow solidsolution domains being observed at the two ends of the electrochemical process [19].

The $\mathrm{C}-\mathrm{LiFePO}{ }_{4}$ composite, synthesized after a short thermal treatment at $800^{\circ} \mathrm{C}$ and called $\mathrm{Fe}_{800-\text { fast }}$ in ref. [20], shows after a few charge/discharge cycles at room temperature promising electrochemical properties $(\sim 160 \mathrm{mAh} / \mathrm{g}$ at $\mathrm{C} / 20)$. The present paper focuses thus on the study of its electrochemical performances, upon long range cycling in laboratory lithium cells at room temperature, $40^{\circ} \mathrm{C}$ or $60^{\circ} \mathrm{C}$. X-ray diffraction and structural Rietveld refinements were also used to check for possible structural changes for $\mathrm{LiFePO}_{4}$ after cycling. Whatever the positive electrode material, and perhaps especially in the case of nanosize materials such as $\mathrm{LiFePO}_{4}$, such a study is indeed interesting in order to get more insight in the stability (structural, chemical and surface) of the material upon long range cycling in classical conditions, but also in aging conditions.

\section{Experimental}

$\mathrm{C}-\mathrm{LiFePO}_{4}$ sample was synthesized as described in reference [15] by mechanochemical activation. The reactants, the iron phosphate, synthesized as already described elsewhere [7], and the lithium phosphate (Aldrich), were mixed such as $\mathrm{Li} / \mathrm{Fe} \sim 1.05$. Cellulose (Aldrich) was also initially added. This mixture was ball milled in a planetary mill (Fritsch "Pulverisette 4") using tungsten carbide vessels and agate balls. The resulting mixture was thermal-treated under argon flow in a tubular furnace at $800^{\circ} \mathrm{C}$ and the synthesized sample is called $\mathrm{Fe}_{800}$ in the following. Note that it is called $\mathrm{Fe}_{800-\text { fast }}$ in ref. [20] to 
discriminate with that synthesized at $800^{\circ} \mathrm{C}$ but with a slow thermal treatment.

Electrochemical tests were done on cast electrodes. These electrodes were obtained from a mixture of $80 \mathrm{wt} \% \mathrm{C}-\mathrm{LiFePO}_{4}$ active material with $10 \mathrm{wt} \%$ carbon conductive additive (Super $\mathrm{P}, \mathrm{MMM}$ Carbon), $10 \mathrm{wt} \%$ polyvinylidene fluoride binder (Solef 6020 , Solvay) and $0.8 \mathrm{mg}$ of $\mathrm{N}$-methyl pyrrolidone cast on an aluminum foil. This cast foil was dried one night at $55^{\circ} \mathrm{C}$ and pellets of $10 \mathrm{~mm}$ diameter were punched. These pellets were then pressed at $10 \mathrm{~T} . \mathrm{cm}^{-2}$ and dried $48 \mathrm{~h}$ at $80^{\circ} \mathrm{C}$ under vacuum. Considering the surface and thickness of these pellets, less than $2 \mathrm{mg}$ of active material were present on each electrode, leading to an estimated error of $5 \%$ on the specific capacity. Electrochemical properties of this $\mathrm{C}-\mathrm{LiFePO}_{4}$ active material were studied in coin cells containing also a lithium foil as negative electrode, two Celgard® 2400 separators and a Viledon ${ }^{\circledR}$ propylene foil wetted by a liquid electrolyte $(1 \mathrm{M}$ $\mathrm{LiPF}_{6}$ in a mixture of polyethylene carbonate (PC), ethylene carbonate (EC) and dimethyl carbonate (DMC) (1:1:3)). These coin cells were assembled in a dry box under argon and cycled in galvanostatic mode at a constant $\mathrm{C} / 20$ rate (that corresponds to a theoretical exchange of one electron per formula during charge or discharge in 20 hours). Electrochemical tests were carried out either with home made apparatus or with a Bio-logic VMP1 apparatus. After cycling, the cells were disassembled in a dry box under argon; positive electrodes were rinsed with DMC and dried under vacuum.

Samples for X-ray diffraction (XRD), prepared in the dry box, were maintained in a sample-holder which allows to keep a controlled atmosphere around the sample during more than $24 \mathrm{~h}$. XRD data were collected using a PANalitycal X'pert Pro diffractometer ( $\mathrm{Co} \mathrm{K} \alpha$ radiation, and iron filter, antiscatter slit of $1 / 2^{\circ}$ and divergence slit of $1 / 4^{\circ}$ on the incident beam path). The diffraction patterns were recorded in the $[15-75]^{\circ}(2 \theta)$ angular range using an $0.0167^{\circ}(2 \theta)$ step and a constant counting time of $12 \mathrm{~s}$.

For structural studies, XRD patterns were refined by the Rietveld method using the Fullprof program [21]. The peaks profile was described with the Thompson-Cox-Hastings function to take into account the microstructure (size and strains effects) for this material ( $\mathrm{LaB}_{6}$ was used as standard) [21].

\section{Results and discussion}

As reported elsewhere [15], that C-containing $\mathrm{LiFePO}_{4}$ composite synthesized at $800^{\circ} \mathrm{C}$ under argon appears as a pure olivine phase from an XRD point of view. Note that no observation of carbon was possible suggesting, as expected, the formation of a highly divided carbon (very small coherence length) from decomposition of cellulose at $800^{\circ} \mathrm{C}$. The structure of $\mathrm{LiFePO}_{4}$ phase was described in the Pnma space group with the cell parameters $a=10.3294(2) \AA, \quad b=6.0086(1) \AA$, $c=4.6948(1) \AA$ and thus $V=291.38(1) \AA^{3}$. As expected from the nominal stoichiometry, the $\mathrm{Li} / \mathrm{Fe}$ ratio was found from chemical analysis superior than 1 with a " $\mathrm{Li}_{1.04} \mathrm{Fe}_{0.98} \mathrm{P}$ " chemical formula and $2.9 \mathrm{wt} \%$ of carbon. Furthermore Mössbauer spectroscopy revealed the presence of about 5 at. $\%$ of iron (III). Note that the origin of these iron (III) ions is not yet identified. Indeed, combination of neutron diffraction, magnetic measurements, as well as XPS and Mössbauer spectroscopy (transmission or reflection modes), has only shown that:

- (i) the structural model $\mathrm{Li}\left(\mathrm{Li}_{1-\mathrm{x}} \mathrm{Fe}_{\mathrm{x}}\right) \mathrm{PO}_{4}$ is not valid for $\mathrm{LiFePO}_{4}$ and can thus not explain the $\mathrm{Li} / \mathrm{Fe}$ ratio larger than 1 and the presence of iron (III) in the sample,

- (ii) no ferromagnetic and crystallized containing $\mathrm{Fe}(\mathrm{III})$ rich impurities such as $\mathrm{Fe}_{2} \mathrm{O}_{3}$ and $\mathrm{Fe}_{2} \mathrm{P}[4,22]$ are detected in the sample,

- (iii) surface study techniques do not show the presence of iron (III) surface defects or of a preferential presence of the iron (III) rich phase at the surface.

Nevertheless, note that in some experimental conditions, a small amount of $\mathrm{Li}_{9} \mathrm{Fe}_{3}\left(\mathrm{P}_{2} \mathrm{O}_{7}\right)_{3}\left(\mathrm{PO}_{4}\right)_{2}$ is observed as impurity. As in the sample concerned by this work the $\mathrm{Li} / \mathrm{Fe}$ ratio is larger than 1 and $\sim 5-6$ at. $\%$ of $\mathrm{Fe}^{3+}$ are observed by Mössbauer spectroscopy, we can assume the presence of such a lithium-rich amorphous phase with trivalent iron, especially in synthesis with a very short thermal treatment.

\section{Long range electrochemical experiments at different temperatures}

Long range cycling experiments were carried out at various temperatures $\left(\mathrm{RT}, 40^{\circ} \mathrm{C}\right.$ and $\left.60^{\circ} \mathrm{C}\right)$ in the $[2-4.5] \mathrm{V} \mathrm{vs.} \mathrm{Li}^{+} / \mathrm{Li}$ voltage window to study for possible changes in the electrochemical behaviour and the structure stability. Fig. 1a gives a comparison of the charge and discharge curves obtained at $\mathrm{C} / 20$ rate for the $1^{\text {st }}, 20^{\text {th }}, 70^{\text {th }}$ and $100^{\text {th }}$ cycles at room temperature. Note that for an easier comparison we have chosen to apply a vertical $0.1 \mathrm{~V}$ shift to the charge and discharge curves reported in Fig. 1. Fig. 2 gives capacity change, for an $\mathrm{Li} \| \mathrm{C}-\mathrm{LiFePO}_{4}\left(\mathrm{Fe}_{800}\right)$ cell charged up to $4.5 \mathrm{~V}$ vs. $\mathrm{Li}^{+} / \mathrm{Li}$ and discharged down to $2 \mathrm{~V} v s$. $\mathrm{Li}^{+} / \mathrm{Li}$ at room temperature. The average reversible capacity obtained in discharge is maintained over the 100 cycles around $160 \mathrm{mAh} / \mathrm{g}$, that value being close to the theoretical one $(\sim 170 \mathrm{mAh} / \mathrm{g})$. The shape of the charge and discharge curves shows almost no change even after one hundred cycles, in good agreement with the good capacity retention observed upon long range cycling for $\mathrm{Fe}_{800}$ when used as positive electrode in lithium cells. Nevertheless, note that the first cycle is different from the next ones, with higher polarizations at the end of the first charge and discharge, those suggesting that complete lithium deintercalation and intercalation are getting difficult due to limited electronic and/or ionic conductivities. Note also that the difference between the charge and discharge voltage plateau remains small and constant $(\sim 0.10 \mathrm{~V})$ upon long range cycling and that the irreversible capacity at the end of the first cycle is rather small $(\Delta \mathrm{x} \sim 0.05$, i.e. $\sim 9 \mathrm{mAh} / \mathrm{g})$. Consequently, $\mathrm{Fe}_{800}$ exhibits good and stable electrochemical performances upon long range cycling at room temperature. These results are in rather good agreement with those recently reported by Amine et al. (capacity of $140 \mathrm{mAh} / \mathrm{g}$ at $\mathrm{C} / 3$ rate up to 100 cycles) for $\mathrm{LiFePO}_{4}$ materials synthesized by solid-state reaction and coated with $\sim 3.5 \mathrm{wt} \%$ of carbon [23].

Fig. 1b gives a comparison of charge and discharge curves for a $\mathrm{Li} \| \mathrm{C}-\mathrm{LiFePO}_{4}\left(\mathrm{Fe}_{800}\right)$ cell cycled at $40^{\circ} \mathrm{C}$ and at $\mathrm{C} / 20$ rate in the $[2-4.5] \mathrm{V}$ vs. $\mathrm{Li}^{+} / \mathrm{Li}$ voltage window, the corresponding specific capacity change upon 100 cycles is given in Fig. 2. Good capacity retention is observed during 50 cycles with an average reversible capacity around $155 \mathrm{mAh} / \mathrm{g}$ (equal within the 
error on the active mass to that previously reported at RT). As a consequence of increased conductivities at higher temperature, the irreversible capacity and the voltage difference between charge and discharge plateau are slightly smaller than those observed at room temperature. They are equal to $\sim 7 \mathrm{mAh} / \mathrm{g}$ $(\Delta \mathrm{x} \sim 0.04)$ and to $\sim 0.08 \mathrm{mV}$ respectively. Considering that the lithium test cells were coin cells made in our lab (i.e. in non optimized conditions), $\mathrm{Li} \| \mathrm{C}-\mathrm{LiFePO}_{4}$ cells with $\mathrm{Fe}_{800}$ as positive electrode material show very promising cycling stability even when cycled at $40^{\circ} \mathrm{C}$, indeed more than $80 \%$ of the initial reversible capacity is still maintained after 100 cycles. Note that the profile of the first cycle (ends of the $1^{\text {st }}$ charge and discharge) is significantly modified with a temperature increase from RT to $40^{\circ} \mathrm{C}$.
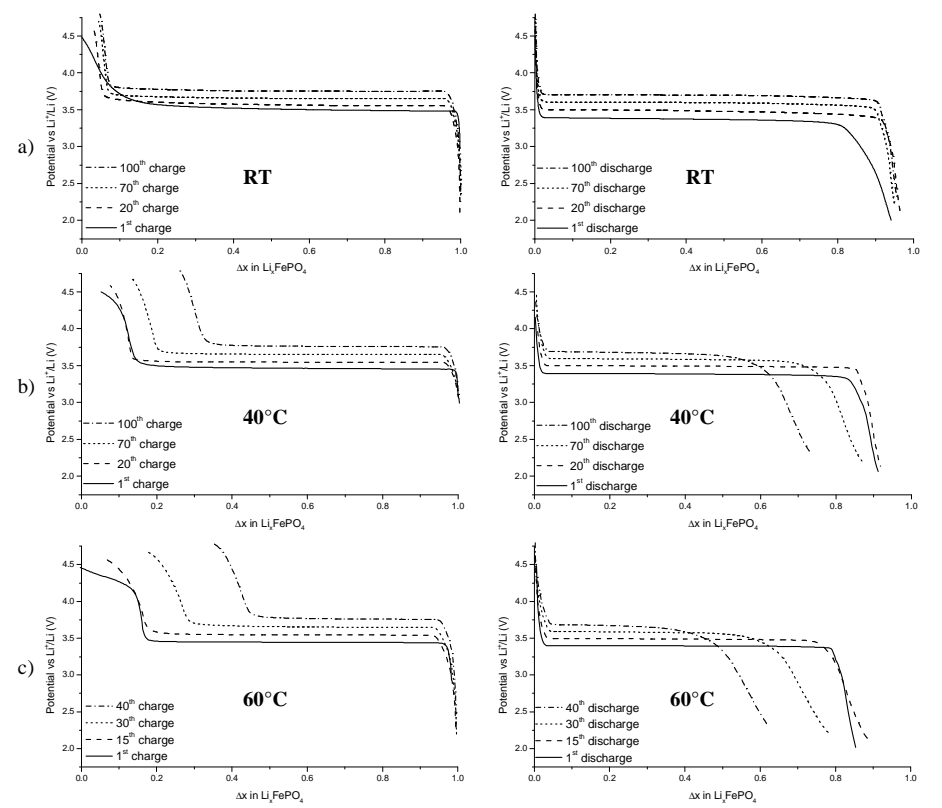

Fig. 1: Cycling curves obtained for $\mathrm{Li} \| \mathrm{C}-\mathrm{LiFePO}_{4}\left(\mathrm{Fe}_{800}\right)$ cells in the $[2-4.5 \mathrm{~V}]$ vs. $\mathrm{Li}^{+} / \mathrm{Li}$ voltage window, at $\mathrm{C} / 20$ rate and at $\mathrm{RT}(\mathrm{a}), 40^{\circ} \mathrm{C}$ (b) and $60^{\circ} \mathrm{C}(\mathrm{c})$. Comparison of the charge curves and discharge curves obtained during the $1^{\text {st }}, 20^{\text {th }}, 70^{\text {th }}$ and $100^{\text {th }}$ cycles for cyclings at RT and $40^{\circ} \mathrm{C}$ and during the $1^{\text {st }}$, $15^{\text {th }}, 30^{\text {th }}$ and $40^{\text {th }}$ cycles for cycling at $60^{\circ} \mathrm{C}$. Each charge / discharge curve is shifted from the previous reported one of $0.1 \mathrm{~V}$ for an easier comparison (note that the first charge and discharge are not shifted).

Fig. 1c presents the results obtained for a similar study performed at even higher temperature, i.e. at $60^{\circ} \mathrm{C}$. The tendency observed at $40^{\circ} \mathrm{C}$ is emphasized at $60^{\circ} \mathrm{C}$, the loss of capacity is faster, about $40 \%$ of the capacity is lost after only 40 cycles. The electrochemical characteristics - reversible capacity of $\sim 150 \mathrm{mAh} / \mathrm{g}$ and difference between charge and discharge voltage plateau of $\sim 0.06 \mathrm{mV}$ - observed at the beginning of the electrochemical tests are rather similar to those found at RT and at $40^{\circ} \mathrm{C}$. Note that there is an increase of the irreversible capacity at $60^{\circ} \mathrm{C} \quad(\sim 25.5 \mathrm{mAh} / \mathrm{g}$ with $\Delta \mathrm{x} \sim 0.15)$. The comparison of the first charge shape at increasing temperature shows the appearance of a new "plateau" above $4 \mathrm{~V} v s . \mathrm{Li}^{+} / \mathrm{Li}$. Nevertheless the shape of the following first discharge is not strongly affected, only a decrease of the first discharge capacity is observed with an increase of the irreversible capacity; this shows that during the $4-4.5 \mathrm{~V} v s$. $\mathrm{Li}^{+} / \mathrm{Li}$ plateau the lithium deintercalation from $\mathrm{LiFePO}_{4}$ is probably still going but together with a secondary process, that is irreversible. This overall phenomenon can be explained if one assume an irreversible electrochemical reaction occurring on the particle surface (electrolyte oxidation or/and material degradation) whose kinetics increases strongly with temperature. Indeed, this reaction, becoming prevalent when the cell voltage would reach a critical value i.e. above $4.13 \mathrm{~V} v s . \mathrm{Li}^{+} / \mathrm{Li}$, grows continuously with temperature as shown in the example reported in Fig. 1. Potentiostatic electrochemical tests done at slow scanning rate $(10 \mathrm{mV}$ steps every hour) and at room temperature show an increase of an oxidation current (and thus a degradation) from $4.1 \mathrm{~V}$ vs. $\mathrm{Li}^{+} / \mathrm{Li}$ for the electrolyte used $\left(\mathrm{LiPF}_{6}(1 \mathrm{M})\right.$ in a mixture of propylene carbonate (PC), ethylene carbonate (EC) and dimethyl carbonate (DMC) (1:1:3)). We thus assume that the electrochemical reaction occurring at high voltage is associated to the electrolyte degradation, which is promoted by an increase of the cycling temperature in presence of this highly divided $\mathrm{C}-\mathrm{LiFePO}_{4}$ material. The greater this electrolyte degradation occurs, the faster the capacity fades. This phenomenon can explain the high irreversible capacity obtained for $\mathrm{Li} \| \mathrm{Fe}_{800}$ cycled at $60^{\circ} \mathrm{C}$, which is indeed partially due to the irreversible capacity associated with the irreversible oxidation of the electrolyte. Moreover, the larger polarization observed at the end of this first charge should decrease with increasing temperature, whereas reverse is effectively observed; thus another effect as electrolyte degradation has to be considered to explain, at least in part, this increase in polarization.

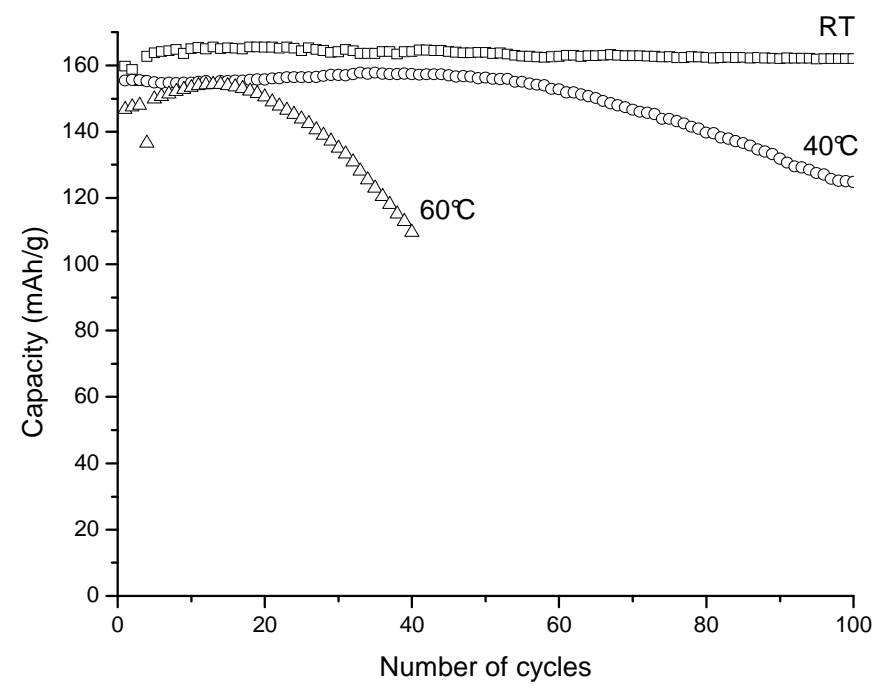

Fig. 2: Evolution of the reversible capacity vs. the number of cycles for $\mathrm{Li} \| \mathrm{C}-\mathrm{LiFePO}_{4}\left(\mathrm{Fe}_{800}\right)$ cells cycled in the $[2-4.5] \mathrm{V}$ vs. $\mathrm{Li}^{+} / \mathrm{Li}$ voltage window, at $\mathrm{C} / 20$ rate and at $\mathrm{RT}, 40^{\circ} \mathrm{C}$ and $60^{\circ} \mathrm{C}$.

Note that the building of a new coin cell (with fresh electrolyte, separators and lithium negative electrode) using the positive electrode recovered from the cell presented in Fig. 1c 
leads to the recovering of a discharge capacity around $150 \mathrm{mAh} / \mathrm{g}$. It reveals that the capacity loss observed upon cycling, at $60^{\circ} \mathrm{C}$ for instance, is more probably due to a wetting problem of the positive electrode due to the electrolyte degradation or to a lithium electrode degradation than to the formation of degradation products at the surface of the positive electrode that would lead to increasing resistance.

Using first-principles methods Morgan et al. have recently shown that lithium diffusion occurs through one-dimensional channels along $b$-axis in olivine-type structures and is one order of magnitude faster in $\mathrm{Li}_{\varepsilon} \mathrm{FePO}_{4}$ in comparison to $\mathrm{Li}_{1-\varepsilon} \mathrm{FePO}_{4}$ [24]. This result implies significantly different transport properties upon charge and discharge and is in agreement with the observation by Srinivasan et al. $[25,26]$ of an asymmetric behavior between charge and discharge, i.e. a significantly more efficient charge in comparison to discharge in transport limitations conditions. As observed in Fig. 1a, large polarization is observed at the end of the first discharge: in that case it could be well explained by transport limitations because it decreases with an increase in temperature (see Figs. $1 b-c$ ).

\section{$\underline{X}$-ray diffraction study of the materials recovered after long range cycling}

The materials recovered after these experiments, i.e. long range cyclings at room temperature, $40^{\circ} \mathrm{C}$ and $60^{\circ} \mathrm{C}$, were studied from a structural point of view by $\mathrm{X}$-ray diffraction. They are respectively associated to $\mathrm{Fe}_{800}-\mathrm{RT}-100$ cycles, $\mathrm{Fe}_{800}-40^{\circ} \mathrm{C}-100$ cycles and $\mathrm{Fe}_{800}-60^{\circ} \mathrm{C}$-40cycles in the following (for instance, $\mathrm{Fe}_{800}$-RT-100cycles composite to $\mathrm{Fe}_{800}$ cycled at RT during 100 cycles). Fig. 3 compares their X-ray diffraction patterns with those recorded for the pristine material $\mathrm{Fe}_{800}$ and for $\mathrm{Fe}_{800}$ recovered after a first $1 / 2$ charge $\left(\mathrm{Fe}_{800}-\mathrm{RT}-1 / 2\right.$ charge $)$, after a first charge $\left(\mathrm{Fe}_{800}-\mathrm{RT}\right.$-1 charge), after a first charge and a first $1 / 2$ discharge $\left(\mathrm{Fe}_{800}-\mathrm{RT}-1 / 2\right.$ discharge), and finally after one cycle $\left(\mathrm{Fe}_{800}-\mathrm{RT}-1\right.$ cycle). Note that these latter materials were obtained upon cycling at $\mathrm{C} / 20$ and $\mathrm{RT}$.

The XRD patterns associated to $\mathrm{Fe}_{800}-\mathrm{RT}-1 / 2$ charge and to $\mathrm{Fe}_{800}$-RT-1/2discharge are characteristic of a two-phase mixture, as expected from the biphased mechanism observed at $\sim 3.45 \mathrm{~V}$ vs. $\mathrm{Li}^{+} / \mathrm{Li}$ between the compositions $\mathrm{Li}_{1-\mathcal{\varepsilon}} \mathrm{FePO}_{4}$ and $\mathrm{Li}_{\mathcal{\varepsilon}}, \mathrm{FePO}_{4}$. The XRD patterns recorded at the end of the first charge and first discharge are characteristic of single phases, in good agreement with lithium compositions close to $\mathrm{x}=0$ and $\mathrm{x}=1$ for $\mathrm{Li}_{x} \mathrm{FePO}_{4}$ and belonging thus to the solid-solution domains observed at the very ends of the charge and discharge processes [19]. $\mathrm{Fe}_{800}-\mathrm{RT}-100$ cycles recovered after a long range cycling at room temperature shows a XRD pattern characteristic of a single-phase, that being a lithium-rich phase $\left(\mathrm{Li}_{1-\varepsilon} \mathrm{FePO}_{4}\right.$-type), whereas both $\mathrm{Fe}_{800}-40^{\circ} \mathrm{C}-100$ cycles and $\mathrm{Fe}_{800}-60^{\circ} \mathrm{C}-40$ cycles are two-phase mixtures, the main phase being the lithium-rich phase $\mathrm{Li}_{1-\varepsilon} \mathrm{FePO}_{4}$ and the other the lithium-deficient phase $\mathrm{Li}_{\varepsilon}, \mathrm{FePO}_{4}$. Note that extra-peaks are observed in the $[15-22]^{\circ}$ angular range on the XRD patterns recorded for the electrodes cycled at $40^{\circ} \mathrm{C}$ and $60^{\circ} \mathrm{C}$. They were identified and associated to the Celgard ${ }^{\circledR}$ separator, indeed during the disassembling of the battery after cycling in temperature, the positive electrodes were recovered stuck on the separator instead of being cast on the aluminium foil. As shown in Fig. 3, there is an overlapping between these extra-peaks and the (200) peaks of the olivine- type phases. In the following, the $[15-22]^{\circ}$ angular domain has thus to be excluded for the Rietveld refinement.

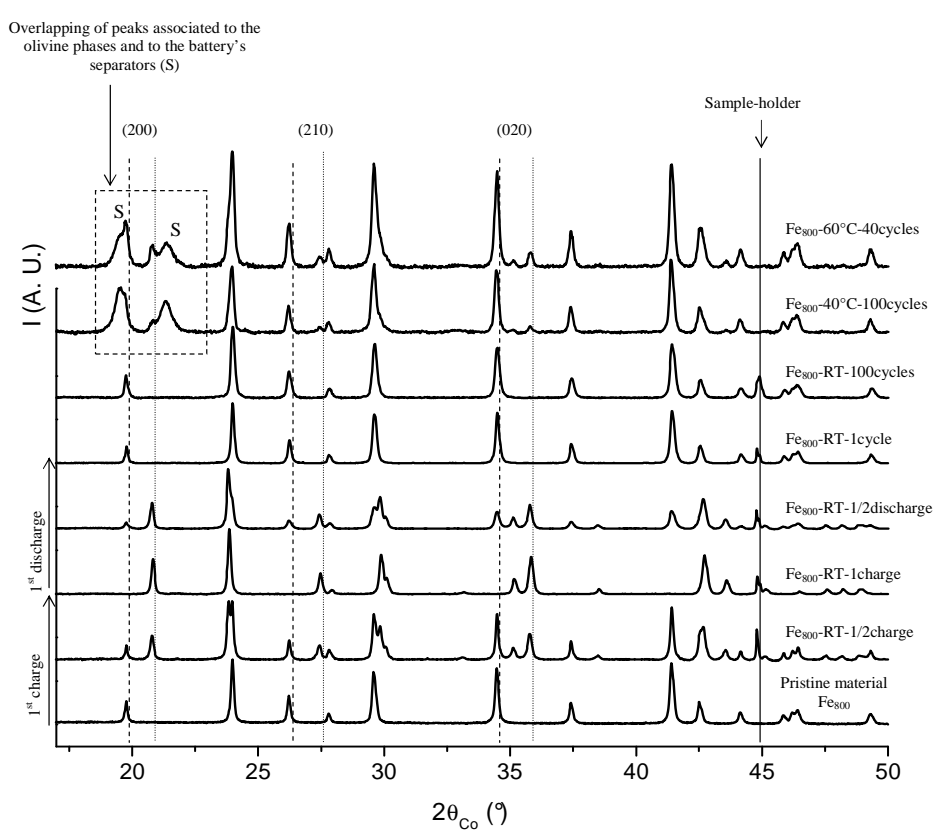

Fig. 3 : Comparison of the X-ray diffraction patterns recorded for the pristine material $\mathrm{Fe}_{800}, \mathrm{Fe}_{800}$ after $1 / 2$ charge at $\mathrm{C} / 20$ and at room temperature ( $\mathrm{Fe}_{800}$-RT-1/2charge), $\mathrm{Fe}_{800}$ after a first charge at $\mathrm{C} / 20$ and at room temperature $\left(\mathrm{Fe}_{800}-\mathrm{RT}\right.$-1 charge), $\mathrm{Fe}_{800}$ after a first charge and $1 / 2$ first discharge at $\mathrm{C} / 20$ and at room temperature $\left(\mathrm{Fe}_{800}-\mathrm{RT}-1 / 2\right.$ discharge $), \mathrm{Fe}_{800}$ at the end of a first electrochemical cycle at $\mathrm{C} / 20$ and at room temperature ( $\mathrm{Fe}_{800}-\mathrm{RT}-1$ cycle), $\mathrm{Fe}_{800}$ after 100 cycles at $\mathrm{C} / 20$ rate and at room temperature ( $\mathrm{Fe}_{800}-\mathrm{RT}-100$ cycles), $\mathrm{Fe}_{800}$ after 100 cycles at $\mathrm{C} / 20$ rate and at $40^{\circ} \mathrm{C}\left(\mathrm{Fe}_{800}-40^{\circ} \mathrm{C}-100\right.$ cycles $)$ and $\mathrm{Fe}_{800}$ after 40 cycles at $\mathrm{C} / 20$ rate and at $60^{\circ} \mathrm{C}\left(\mathrm{Fe}_{800}-60^{\circ} \mathrm{C}-40\right.$ cycles $)$.

In order to determine accurately the structure of $\mathrm{Fe}_{800}$-RT-100cycles and to identify possible changes versus that of the pristine material $\mathrm{Fe}_{800}$, refinement by the Rietveld method of the XRD data was performed using the Fullprof program [21]. Firstly, a full pattern matching refinement allowed to determine the lattice parameters - the unit cell was described in the Pnma orthorhombic space group with $a=10.3224(5) \AA$, $b=6.0025(3) \AA$ and $c=4.6988(3) \AA \quad$ and the profile parameters of the Pseudo-Voigt function used to describe the shape of the diffraction lines. Then, the structural refinement was carried out by considering the $[\mathrm{Li}]_{4 \mathrm{a}}[\mathrm{Fe}]_{4 \mathrm{c}} \mathrm{PO}_{4}$ structural hypothesis. The $\mathrm{Li} / \mathrm{Fe}$ ratio being very close to 1 , it was thus fixed to 1. The isotropic atomic displacement parameters (Biso $\left(\AA^{2}\right)$ ) were refined. All the structural and profile parameters obtained by the refinement by the Rietveld method of the XRD data recorded for $\mathrm{Fe}_{800}-\mathrm{RT}-100$ cycles are given in Table 1, whereas Fig. 4 gives a comparison of the experimental and calculated XRD patterns. The small reliability factors $\left(R_{w p}=12.8 \%\right.$ and $\left.R_{B}=5.57 \%\right)$ and the rather good minimization of the difference $\left|I_{o b s}-I_{\text {calc }}\right|$ function suggests a good description of the structure of $\mathrm{Fe}_{800}$-RT-100cycles by the structure of the lithium-rich olivine-type phase. The main structural parameters determined for the $\mathrm{Fe}_{800}$ and $\mathrm{Fe}_{800}$-RT-1cycle materials are summarized in Table 2 for comparison. The cell parameters and the cell volume $\left(V=290.52(3) \AA^{3}\right.$ for $\mathrm{Fe}_{800}-\mathrm{RT}-100$ cycles $)$ are slightly smaller than those determined for the pristine material $\mathrm{Fe}_{800}$ 
$\left(V=291.38(1) \AA^{3}\right)$ and for $\mathrm{Fe}_{800}-\mathrm{RT}-1$ cycle $\left(V=290.95(4) \AA^{3}\right)$ (Table 2), the cell volume decrease being associated to a decreasing lithium amount in the solid-solution phase $\mathrm{Li}_{1-\varepsilon} \mathrm{FePO}_{4}$, as expected after an increasing number of cycles. Comparison of average bonds of $\mathrm{Fe}_{800}$-RT-100cycles $\left(\mathrm{P}-\mathrm{O} \sim 1.54 \AA\right.$, $\quad \mathrm{Fe}-\mathrm{O} \sim 2.16 \AA, \quad \mathrm{Li}-\mathrm{O} \sim 2.15 \AA$ ) with $\mathrm{Fe}_{800}$ $(\mathrm{P}-\mathrm{O} \sim 1.54 \AA$ A $, \quad \mathrm{Fe}-\mathrm{O} \sim 2.17 \AA, \quad \mathrm{Li}-\mathrm{O} \sim 2.14 \AA) \quad$ shows no significant change.

Table 1: Structural and profile parameters obtained by the Rietveld refinement of the X-ray diffraction pattern recorded for $\mathrm{Fe}_{800}$ after 100 cycles at $\mathrm{C} / 20$ and at room temperature $\left(\mathrm{Fe}_{800}-\mathrm{RT}-100\right.$ cycles $)$.

\begin{tabular}{l} 
Feso0-RT-100cycles \\
Space group : Pnma \\
$\begin{array}{l}\mathrm{a}=10.3224(5) \AA \\
\mathrm{b}=6.0025(3) \AA \\
\mathrm{c}=4.6888(3) \AA\end{array}$ \\
\hline \\
\hline
\end{tabular}

\section{Profile parameters :
Thompson-Cox-Hastings function}

$$
\begin{aligned}
& Y=0.088(4) \\
& U=0.12(1) \\
& V=-0.0017 \text { fixed }^{*} \\
& W=0.00383 \text { fixed }^{*}
\end{aligned}
$$

* $\mathrm{LaB}_{6}$ used as standard

\section{Conventional Rietveld R-factors for points with Bragg contribution $\mathrm{R}_{\mathrm{wp}}=12.8 \% ; \mathrm{R}_{\mathrm{B}}=5.57 \%$}

Note: standard deviations have been multiplied by 3 , the Scor parameter being 2.75 .

For $\mathrm{Fe}_{800}$-RT-100cycles, structural study shows that there is no significant structural change of $\mathrm{Fe}_{800}$ after 100 cycles between 2 and $4.5 \mathrm{~V} v s . \mathrm{Li}^{+} / \mathrm{Li}$ at $\mathrm{C} / 20$ rate and at room temperature.

The electrode material recovered after long range cycling at $40^{\circ} \mathrm{C}$ was also characterized from a structural point of view using X-ray diffraction. As already mentioned, the angular range $\left[15^{\circ}-22\right]^{\circ}$ had to be excluded for the Rietveld refinement due to an overlapping of the (200) diffraction lines associated to the olivine-type phases and those of the Celgard ${ }^{\circledR}$ separators. A very similar Rietveld refinement - to that described just previously - was performed to analyze the $\mathrm{Fe}_{800}-40^{\circ} \mathrm{C}-100$ cycles $\mathrm{X}$-ray diffraction data, except that two phases were taken into account. Both phases were described by the olivine-type structure and the structural model $\left[\mathrm{Li}_{\mathrm{x}}\right]_{4 \mathrm{a}}[\mathrm{Fe}]_{4 \mathrm{c}} \mathrm{PO}_{4}$, $\mathrm{x}$ being fixed to 1 and 0 for the lithium-rich $\mathrm{Li}_{1-\varepsilon} \mathrm{FePO}_{4}$ and lithium-deficient $\mathrm{Li}_{\varepsilon}, \mathrm{FePO}_{4}$ phases, respectively. Fig. 5 gives the comparison of the experimental and calculated X-ray diffraction patterns. A good minimization of the $\left|\mathrm{I}_{\text {obs. }}-\mathrm{I}_{\text {calc. }}\right|$ difference and rather small reliability factors $\mathrm{R}_{\mathrm{wp}}=14.4 \%, \quad \mathrm{R}_{\mathrm{B}(\mathrm{Li} \text {-rich })}=5.84 \%$ and $\mathrm{R}_{\mathrm{B} \text { (Li-deficient) }}=11.8 \%$ are obtained, showing that this two-phase mixture with olivine-type structures describes well the $\mathrm{Fe}_{800}-40^{\circ} \mathrm{C}-100$ cycles XRD pattern. As shown in Table 2, the cell parameters determined for these two phases are in rather good agreement with those determined for $\mathrm{Fe}_{800}$-RT-1/2discharge, that sample being also biphasic and obtained after a partial discharge. Again for $\mathrm{Fe}_{800^{-}}-40^{\circ} \mathrm{C}-100$ cycles, there are no modifications of the structure, the bond lengths are very close to those determined for $\mathrm{Fe}_{800}$.

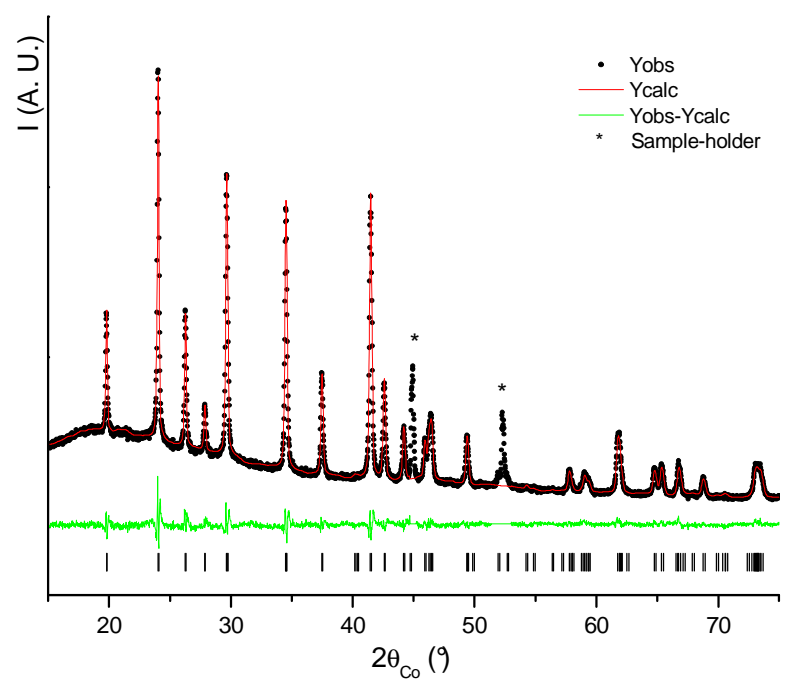

Fig. 4: Comparison of the experimental and calculated $\mathrm{X}$-ray diffraction patterns of $\mathrm{Fe}_{800}$ recovered after 100 cycles of an $\mathrm{Li} \| \mathrm{C}-\mathrm{LiFePO}_{4}\left(\mathrm{Fe}_{800}\right)$ cell between 2 and $4.5 \mathrm{~V} v s . \mathrm{Li}^{+} / \mathrm{Li}$, at a $\mathrm{C} / 20$ rate and at $\mathrm{RT}\left(\mathrm{Fe}_{800}-\mathrm{RT}-100\right.$ cycles $)$.

Exactly the same refinement procedure as that used for $\mathrm{Fe}_{800^{-}}-40^{\circ} \mathrm{C}$-100cycles XRD data was followed for $\mathrm{Fe}_{800}-60^{\circ} \mathrm{C}-40$ cycles. A two-phase mixture was also considered. Fig. 5 gives the comparison of the experimental and calculated X-ray diffraction patterns, which shows a really good minimization of the $\left|\mathrm{I}_{\text {obs. }}-\mathrm{I}_{\text {calc. }}\right|$ difference. As expected from Fig. 6 the reliability factors calculated for the lithiated phase are small $\quad \mathrm{R}_{\mathrm{wp}}=13.1 \%, \quad \mathrm{R}_{\mathrm{B}(\mathrm{Li} \text {-rich })}=4.27 \% \quad$ and $\mathrm{R}_{\mathrm{B}(\mathrm{Li} \text {-deficient) }}=9.86 \%$. Note that all the structural parameters (as reported in Table 2 for instance for the cell parameters) determined for $\mathrm{Fe}_{800}-60^{\circ} \mathrm{C}-40$ cycles are similar to those calculated for $\mathrm{Fe}_{800^{-}}-40^{\circ} \mathrm{C}-100$ cycles, showing that no significant structural change occurs upon cycling at high temperature up to $60^{\circ} \mathrm{C}$.

Despite no significant structural change was detected for materials cycled either at RT or at high temperature, we can not exclude the possibility for iron dissolution upon long range cycling of $\mathrm{C}-\mathrm{LiFePO}_{4}$ composites. Indeed, according to Amine et al. the dissolution of iron into the electrolyte would be due to the iron dissolution from the positive electrode [23]. Nevertheless, Koltypin et al. suggest that iron dissolution occurs only in presence of water or acidic species in the electrolyte due 
to the formation of HF [27]. Furthermore, results reported recently by Axmann et al. suggest that the iron dissolution would be probably linked to the presence of impurities, indeed they have shown that an $\mathrm{Fe}_{2} \mathrm{P}$ content leads to higher iron concentrations in the electrolyte after storage at $60^{\circ} \mathrm{C}$ for two weeks. This latter study also shows that, despite this iron dissolution problem, $\mathrm{LiFePO}_{4}$ material shows excellent storage stability in electrolyte in comparison with other commercial positive electrode materials such as $\mathrm{LiNi}_{1 / 3} \mathrm{Co}_{1 / 3} \mathrm{Al}_{1 / 3} \mathrm{O}_{2}$, $\mathrm{LiMn}_{2} \mathrm{O}_{4} \ldots[28]$.

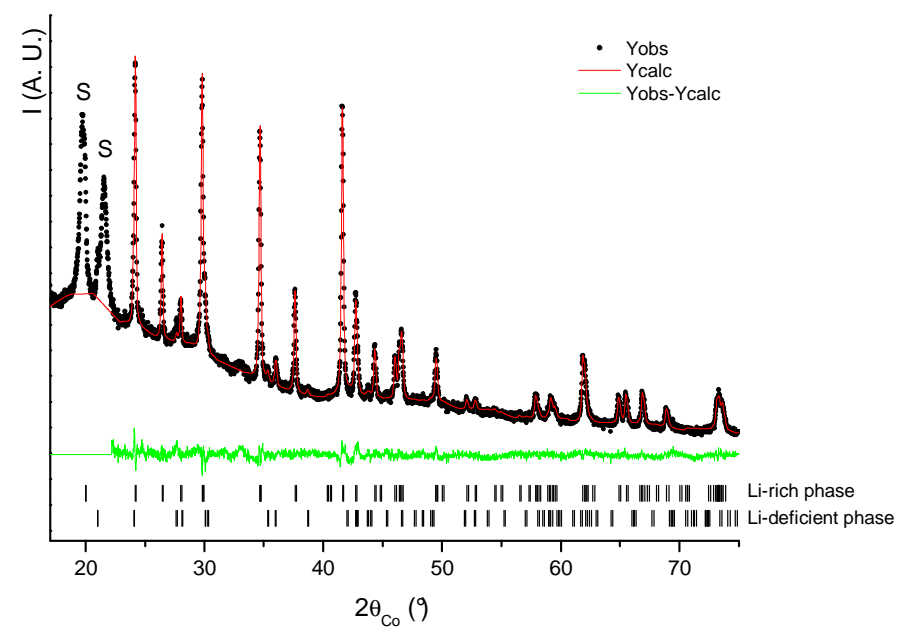

Fig. 5: Comparison of the experimental and calculated X-ray diffraction patterns of $\mathrm{Fe}_{800}$ recovered after 100 cycles of an $\mathrm{Li} \| \mathrm{C}-\mathrm{LiFePO}_{4}\left(\mathrm{Fe}_{800}\right)$ cell between 2 and $4.5 \mathrm{~V}$ vs. $\mathrm{Li}^{+} / \mathrm{Li}$, at a $\mathrm{C} / 20$ rate and at $40^{\circ} \mathrm{C}\left(\mathrm{Fe}_{800}-40^{\circ} \mathrm{C}-100\right.$ cycles $)$.

Table 2: Comparison of the cell parameters obtained by the Rietveld refinement of the X-ray diffraction patterns recorded for the pristine material $\mathrm{Fe}_{800}, \mathrm{Fe}_{800}$ after $1 / 2$ charge at $\mathrm{C} / 20$ and at room temperature $\left(\mathrm{Fe}_{800}-\mathrm{RT}-1 / 2\right.$ charge), $\mathrm{Fe}_{800}$ after a first charge at $\mathrm{C} / 20$ and at room temperature ( $\mathrm{Fe}_{800}-\mathrm{RT}$-1charge), $\mathrm{Fe}_{800}$ after a first charge and a $1 / 2$ first discharge at $\mathrm{C} / 20$ and at room temperature $\left(\mathrm{Fe}_{800} \mathrm{RT}-1 / 2\right.$ discharge $), \mathrm{Fe}_{800}$ at the end of a first electrochemical cycle at $\mathrm{C} / 20$ and at room temperature $\left(\mathrm{Fe}_{800}-\mathrm{RT}-1\right.$ cycle), $\mathrm{Fe}_{800}$ after 100 cycles at $\mathrm{C} / 20$ rate and at room temperature ( $\left.\mathrm{Fe}_{800}-\mathrm{RT}-100 \mathrm{cycles}\right)$, $\mathrm{Fe}_{800}$ after 100 cycles at $\mathrm{C} / 20$ rate and at $40^{\circ} \mathrm{C}$ ( $\mathrm{Fe}_{800}-40^{\circ} \mathrm{C}-100$ cycles) and $\mathrm{Fe}_{800}$ after 40 cycles at $\mathrm{C} / 20$ rate and at $60^{\circ} \mathrm{C}\left(\mathrm{Fe}_{800}-60^{\circ} \mathrm{C}-40\right.$ cycles $)$.

\begin{tabular}{|c|c|c|c|c|}
\hline & $\mathbf{a}(\stackrel{\AA}{\mathbf{A}})$ & $\mathbf{b}(\stackrel{\mathbf{A}}{)})$ & c $(\stackrel{\mathbf{A}}{)}$ & $\mathbf{V}\left(\AA^{3}\right)$ \\
\hline \multirow[t]{2}{*}{$\mathrm{Fe}_{800}-60^{\circ} \mathrm{C}-40 \mathrm{cycles}$} & $10.3263(6)$ & $6.0057(4)$ & $4.6931(4)$ & $291.05(4)$ \\
\hline & $9.821(2)$ & $5.7917(9)$ & $4.7852(8)$ & $272.17(9)$ \\
\hline \multirow[t]{2}{*}{$\mathrm{Fe}_{800^{-}}-40^{\circ} \mathrm{C}-100 \mathrm{cycles}$} & $10.3236(6)$ & $6.0042(4)$ & $4.6926(4)$ & $290.87(3)$ \\
\hline & $9.822(8)$ & $5.790(1)$ & $4.782(2)$ & $271.9(3)$ \\
\hline Fe $_{800}$-RT-100cycles & $10.3224(5)$ & $6.0025(3)$ & $4.6888(3)$ & $290.52(3)$ \\
\hline $\mathrm{Fe}_{800}$-RT-1cycle & $10.3239(6)$ & $6.0050(4)$ & $4.6932(4)$ & $290.95(4)$ \\
\hline \multirow{2}{*}{$\mathrm{Fe}_{800}-\mathrm{RT}$-1/2discharge } & $10.314(1)$ & $6.0011(8)$ & $4.6941(7)$ & $290.55(7)$ \\
\hline & $9.820(1)$ & $5.7921(5)$ & $4.7796(5)$ & $271.87(5)$ \\
\hline $\mathrm{Fe}_{800}$-RT-1charge & $9.8207(8)$ & $5.7913(4)$ & $4.7798(5)$ & $271.85(4)$ \\
\hline \multirow[t]{2}{*}{ Fe $_{800}$-RT-1/2charge } & $10.3224(6)$ & $6.0043(4)$ & $4.6932(4)$ & $290.88(4)$ \\
\hline & $9.828(1)$ & $5.7955(4)$ & $4.7815(4)$ & $272.32(4)$ \\
\hline $\mathrm{Fe}_{800}$ (pristine material) & $10.3294(3)$ & $6.0086(2)$ & $4.6948(1)$ & $291.38(1)$ \\
\hline
\end{tabular}

Note that significant iron dissolution into electrolyte would induce capacity fading and that dissolution would be activated by an increase of the cycling temperature. Indeed, these iron ions, even present as traces, would be reduced at the lithium negative electrode and would then prevent any good reversibility of the redox phenomenon due to the poisoning of the negative electrode and to a decrease of the active electrode mass. In our cycling conditions - in comparison with those used by Amine et al. [23] - slower rate $(\mathrm{C} / 20$ vs. $\mathrm{C} / 3)$, higher temperature $\left(60^{\circ} \mathrm{C}\right.$ vs. $\left.55^{\circ} \mathrm{C}\right)$ and higher voltage $(4.5 \mathrm{~V}$ vs. $4.0 \mathrm{~V})$ should have promoted iron dissolution reactions. At the end of the cycling tests, qualitative analyses by X-ray fluorescence spectroscopy were done on different lithium negative electrodes cycled at $60^{\circ} \mathrm{C}$, it was possible to clearly identify the iron $\mathrm{K} \alpha_{1}$ and $\mathrm{K} \beta_{1}$ peaks on the X-ray fluorescence spectra. Nevertheless, quantitative analyses are necessary for correlating clearly the presence of iron at the negative electrode to a possible capacity fading of $\mathrm{C}-\mathrm{LiFePO}_{4}$ composites upon long range cycling, especially in temperature. Analyses of larger negative electrode recovered from larger cells should allow determining the amount and origin of this iron: from $\mathrm{LiFePO}_{4}$ itself or from an impurity?

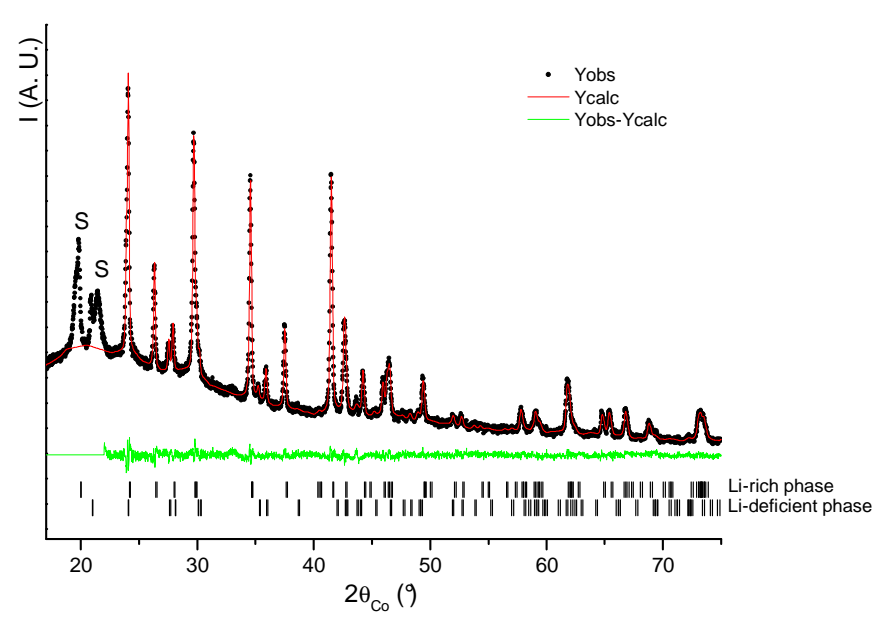

Fig. 6: Comparison of the experimental and calculated X-ray diffraction patterns of $\mathrm{Fe}_{800}$ recovered after 40 cycles of an $\mathrm{Li} \| \mathrm{C}-\mathrm{LiFePO}_{4}\left(\mathrm{Fe}_{800}\right)$ cell between 2 and $4.5 \mathrm{~V}$ vs. $\mathrm{Li}^{+} / \mathrm{Li}$, at a $\mathrm{C} / 20$ rate and at $60^{\circ} \mathrm{C}\left(\mathrm{Fe}_{800}-60^{\circ} \mathrm{C}-40\right.$ cycles $)$.

\section{Conclusions}

This study was focused on the electrochemical performances and structural stability of the $\mathrm{C}-\mathrm{LiFePO}_{4}$ composite $\mathrm{Fe}_{800}$ synthesized after a short thermal treatment at $800^{\circ} \mathrm{C}$ - upon long range cyclings at different temperatures $\left(\mathrm{RT}, 40^{\circ} \mathrm{C}\right.$ and $\left.60^{\circ} \mathrm{C}\right)$ in the [2 - 4.5] $\mathrm{V} v s . \mathrm{Li}^{+} / \mathrm{Li}$ voltage window with a $\mathrm{C} / 20$ rate.

At room temperature, the $\mathrm{Li} \| \mathrm{C}-\mathrm{LiFePO}_{4}\left(\mathrm{Fe}_{800}\right)$ lithium cells show small polarization, good reversible capacity $(\sim 160 \mathrm{mAh} / \mathrm{g})$ and good capacity retention up to 100 cycles. Good capacity retention is also observed during 50 cycles for long range cyclings at $40^{\circ} \mathrm{C}$, with a good reversible capacity $(\sim 155 \mathrm{mAh} / \mathrm{g}$, equal within the error on the active mass to that found at RT) and with smaller irreversible capacity and difference between charge and discharge voltage on the plateau than at room temperature, due to the increase of transport properties at higher temperature. After 100 cycles, more than $80 \%$ of the initial reversible capacity is still maintained; $\mathrm{Li} \| \mathrm{C}-\mathrm{LiFePO}_{4}$ cells with $\mathrm{Fe}_{800}$ as positive electrode material thus show very promising electrochemical performances even 
when cycled at $40^{\circ} \mathrm{C}$. Long range cyclings at $60^{\circ} \mathrm{C}$ have shown as expected a faster loss of capacity: about $40 \%$ of the initial capacity is lost after 40 cycles. Faster degradation of electrochemical performances with the temperature was mainly associated with parasitic reaction above $4.1 \mathrm{~V} v s$. $\mathrm{Li}^{+} / \mathrm{Li}$, as shown by the change in charge profiles - especially the first - at $40^{\circ} \mathrm{C}$ and particularly at $60^{\circ} \mathrm{C}$ compared with those obtained at room temperature.

Materials recovered after long range cyclings were studied from a structural point of view by the Rietveld refinement of their X-ray diffraction data. Materials recovered after long range cycling at RT present a XRD pattern characteristic of a single lithium-rich phase with parameters slightly smaller than those obtained for pristine $\mathrm{Fe}_{800}$ and in good agreement with parameters obtained for $\mathrm{Fe}_{800}$ - RT-1cycle. Moreover, comparison of $\mathrm{P}-\mathrm{O}, \mathrm{Fe}-\mathrm{O}$ and $\mathrm{Li}-\mathrm{O}$ distances shows no significant structural changes. After long range cyclings at $40^{\circ} \mathrm{C}$ and $60^{\circ} \mathrm{C}$, a twophase mixture is obtained with the main phase being the lithiumrich phase $\mathrm{Li}_{1-\varepsilon} \mathrm{FePO}_{4}$ and the other the lithium-deficient phase $\mathrm{Li}_{\varepsilon}, \mathrm{FePO}_{4}$, the two described with an olivine-type structure. Structural parameters obtained by the Rietveld refinement of their XRD data were shown to be in good agreement with those expected for a $\mathrm{Li}_{1-\varepsilon} \mathrm{FePO}_{4}-\mathrm{Li}_{\varepsilon}, \mathrm{FePO}_{4}$ two-phase mixture.

Note that despite no structural change was detected for $\mathrm{Fe}_{800}-60^{\circ} \mathrm{C}-40$ cycles, qualitative analyses by $\mathrm{X}$-ray fluorescence spectroscopy were done on different lithium negative electrodes after cycling at $60^{\circ} \mathrm{C}$. On the X-ray fluorescence spectra, it was possible to clearly identify peaks due to iron. Nevertheless, quantitative analyses, for example on larger negative electrodes recovered from larger cells, are necessary for correlating clearly the presence of iron (amount and origin) at the negative electrode to a possible capacity fading of $\mathrm{C}-\mathrm{LiFePO}_{4}$ composites upon long range cycling, especially in temperature.

Acknowledgements: the authors wish to thank Cathy Denage (ICMCB) and Carole Bourbon (CEA) for technical assistance, Région Aquitaine (CPER Véhicule Electrique 21-13) and Ademe (PVE $n^{\circ}$ 0366C0072) for financial support, CEA and CNRS for funding for Magali Maccario (PhD)

\section{References:}

1 J. S. Weaving, F. Coowar, D. A. Teagle, J. Cullen, V. Dass, P. Bindin, R. Green, W. J. Macklin, J. Power Sources 97-98 (2001) 733.
2 A. K. Padhi, K. S. Nanjundaswamy, J. B. Goodenough, J. Electrochem. Soc. 144 (1997) 1188

3 A. Yamada, Y. Kudo, K.-Y. Liu, J. Electrochem. Soc. 148 (2001) A747.

$4 \quad$ P. S. Herle, B. Ellis, N. Coombs, L. F. Nazar, Nature Mat. 3 (2004), 147 152.

5 C. Delacourt, P. Poizot, M. Morcrette, J. M. Tarascon, C. Masquelier, Chem. Mater., 16 (2004), 93-99.

6 A. S. Andersson, B. Kalska, L. Haggstrom, J. O. Thomas, Solid State Ionics, 130 (2000), 41-52.

7 S. Franger, F. Le Cras, C. Bourbon, H. Rouault, Electrochem. Solid State Lett. 5 (2002), A231-A233.

8 C. Delacourt, J. Rodriguez Carvajal, B. Schmitt, J. M. Tarascon, C. Masquelier, Solid State Sci. 7 (2005), 1506-1516.

9 G. Arnold, J. Garche, R. Hemmer, S. Strobele, C. Vogler, A. Wohlfahrt Mehrens, J. Power Sources 119 Special Iss. SI (2003), 247-251.

10 H. Huang, S.-C. Yin, L. F. Nazar, Electrochem. Solid State Lett. 4 (2001), A170

11 S. Franger, F. Le Cras, C. Bourbon, H. Rouault, J. Power Sources 119 Special Iss. SI (2003), 252-257.

12 S. F. Yang, P. Y. Zavalij, M. S. Whittingham, Electrochem. Commun. 3 (2001), 505-508.

13 F. Croce, A. D. Epifanio, J. Hassoun, A. Deptula, T. Olczac, B. Scrosati, Electrochem. Solid State Lett. 5 (2002), A47-A50.

14 C. Delacourt, P. Poizot, S. Levasseur, C. Masquelier, Electrochem. Solid State Lett. 9 (7) (2006), A352-A355.

15 M. Maccario, L. Croguennec, A. Wattiaux, E. Suard, F. Le Cras, C. Delmas, Solid State Ionics, submitted (2006).

16 N. Ravet, Y. Chouinard, J. F. Magnan, S. Besner, M. Gauthier, M Armand, J. Power Sources 97-8 Special Iss. SI (2001), 503-507.

17 S. Franger, C. Bourbon, F. Le Cras, J. Electrochem. Soc. 151 (2004) A1024-A1027.

18 A. S. Andersson, J. O. Thomas, J. Power Sources 97-8 Special Iss. SI (2001), 498-502.

19 A. Yamada, H. Koizumi, N. Sonoyama, R. Kanno, Electrochem. Solid State Lett. 8 (8) (2005), A409-A413.

20 M. Maccario, L. Croguennec, F. Le Cras, C. Delmas, Solid State Ionics, submitted (2006).

21 J. Rodriguez-Carvajal, Laboratoire Léon Brillouin, http://wwwllb.cea.fr/fullweb/powder.htm, (2004).

22 A. Ait Salah, K. Zaghib, A. Mauger, F. Gendron, C. M. Julien, Phys. Stat. Sol. (a) 203 (2006), R1-R3.

23 K. Amine, J. Liu, I. Belharouak, Electrochem. Commun. 7 (2005), 669673

24 D. Morgan, A. Van der Ven, G. Ceder, Electrochem. Solid State Lett. 7 (2) (2004), A30-A32.

25 V. Srinivasan, J. Newman, J. Electrochem. Soc. 151 (10) (2004) A1517A1529.

26 V. Srinivasan, J. Newman, Electrochem. Solid State Lett. 9 (3) (2006), A110-A114.

27 M. Koltypin, D. Aurbach, L. Nazar, B. Ellis, in IMLB, Biarritz, 2006, p. 174.

28 P. Axmann, C. Stinner, G. Arnold, S. Ströbele, M. Kinyanjui, M. Wohlfahrt-Mehrens, in IMLB, Biarritz, 2006, p. 176 